\title{
BRS Tui: a new Biquinho-type pepper cultivar released by Embrapa
}

\section{Cláudia S da C Ribeiro ${ }^{1}$; Sabrina Isabel C de Carvalho ${ }^{1}$; Ana Gláucia Heinrich ${ }^{1}$; Francisco José B Reifschneider}

'Embrapa Hortaliças, Brasília-DF, Brazil; claudia.ribeiro@embrapa.br; sabrina.carvalho@embrapa.br; aninha_glaucia@hotmail.com; ${ }^{2}$ Embrapa, Secretaria de Pesquisa e Desenvolvimento, Brasília-DF, Brazil; francisco.reifschneider@embrapa.br

\begin{abstract}
The orange-fleshed Biquinho pepper type cultivar BRS Tui was developed by Embrapa Hortaliças to meet the demands of fresh fruit and processing agroindustry of preserves, jellies, flavored oils and vinegar markets. Its fruits are very aromatic, tasty, and crunchy. It is resistant to important diseases, and presents high yield, uniformity and fruit quality. Moreover, 'BRS Tui' fruits are sweet and serve consumers who do not consume hot peppers because of their pungency.
\end{abstract}

Keywords: Capsicum chinense, processing, diseases resistance, genetic breeding.

\section{RESUMO}

BRS Tui: nova cultivar de pimenta Biquinho da Embrapa

A cultivar de pimenta Biquinho BRS Tui, de coloração laranja clara, foi desenvolvida pela Embrapa Hortaliças visando tanto o mercado de frutos frescos como o de processamento de conservas, geleias, azeites e vinagres aromatizados. Seus frutos são muito aromáticos, saborosos, crocantes e doces, não apresentando picância. A cultivar é resistente às principais doenças que afetam a cultura da pimenta $\mathrm{e}$ apresenta elevadas produtividade, uniformidade e qualidade de frutos. Além disso, os frutos atendem aos consumidores que não consomem pimentas picantes.

Palavras-chave: Capsicum chinense, processamento, resistência a doenças, melhoramento genético.

Received on September 4, 2018; accepted on October 9, 2018

$I^{n}$ ne early 1980's, Embrapa Hortaliças launched a Capsicum breeding program, considered the largest public investment in pepper breeding in Brazil, targeting different pepper-types and species (Ribeiro et al., 2015). One of the strategies adopted by the program has been to focus on the development of specific products demanded by the market, with about $80 \%$ of the total resources allocated to this segment; and the allocation of about $20 \%$ of breeding efforts to explore new opportunities and niches (Reifschneider et al., 2013, 2016). Most recent efforts address the development of new, uniform, high yielding, high nutrition, disease resistant orange-fleshed Biquinho type pepper. The Biquinho (little beak) pepper group is highly appreciated by Brazilians because of its distinctive aroma and flavor like other Capsicum chinense pepper-types, but its fruit is sweet (Ribeiro \& Reifschneider, 2008).

In Brazil, the Biquinho-type pepper was apparently initially cultivated in the Triângulo Mineiro region (Carvalho \& Bianchetti, 2008; Heinrich et al., 2015), but nowadays it is cultivated in several Brazilian regions. A typical plant of the Biquinho group is a bush with about 0.5 to $0.7 \mathrm{~m}$ height, and intermediate or erect growth habit. Its pod is pointed, triangular-shaped and it is green when immature and red when ripe. The fruit size ranges from 2.0 to $2.8 \mathrm{~cm}$ long by 1.2 to $1.7 \mathrm{~cm}$ wide (Carvalho et al., 2006; Heinrich et al., 2015). Biquinho pepper fruits are sweet, with pungency ranging from 95 to $270 \mathrm{SHU}$ (Scoville Heat Units) (Heinrich et al., 2015).

\section{PEDIGREE}

'BRS Tui' was derived from a commercial red-fruit Biquinho pepper segregating for fruit color (CNPH 4162), part of the germplasm collection of Capsicum spp. at Embrapa Hortaliças.
Four generations of plant selection and selfing were performed until the progenies showed no segregation. During each generation, selection for horticultural and processing characteristics relevant to the industry was undertaken. Selection was based on plant and fruit traits such as plant height and architecture, fruit shape and size, mature fruit color (orangefleshed), no pungency, high yield, and disease resistance. 'BRS Tui' has been registered (RNC 36495) and protected (DOU 26/12/2017) by the Brazilian Ministry of Agriculture, Livestock and Food Supply (MAPA). Breeders' seed is being made available to interested parties in the private sector.

\section{CHARACTERISTICS AND PERFORMANCE}

'BRS Tui' plants present intermediate growth habit, approximately $0.7 \mathrm{~m}$ 


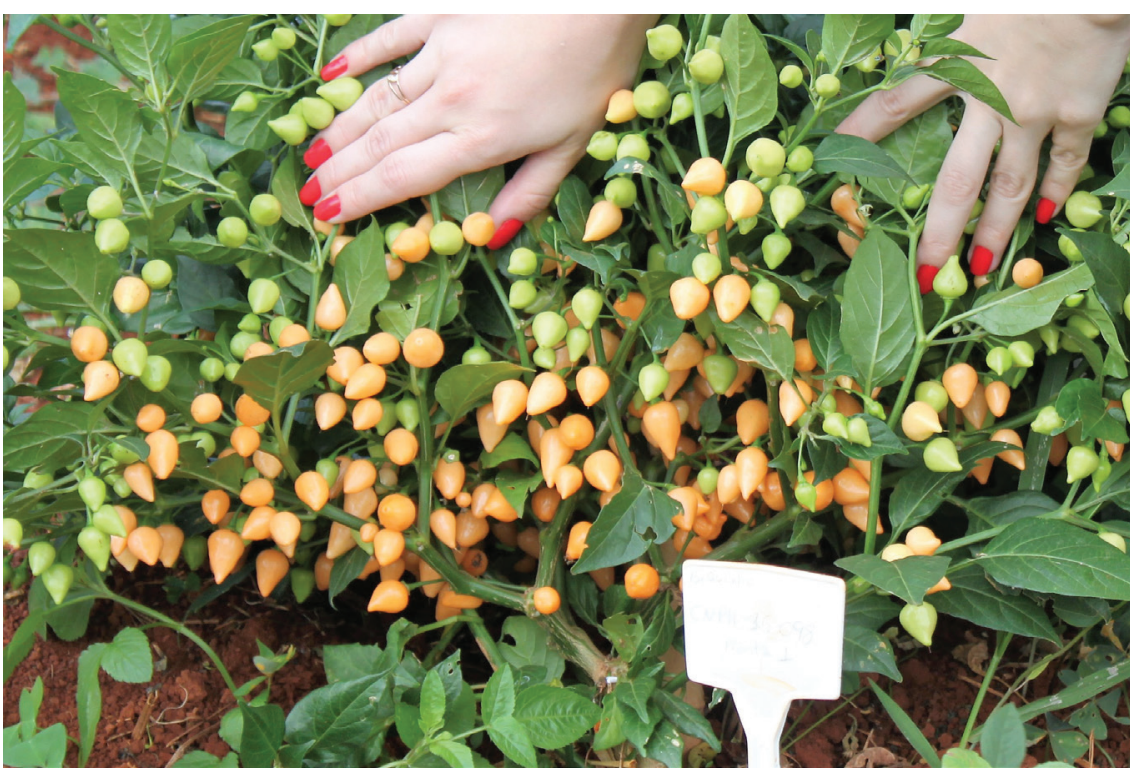

Figure 1. Biquinho pepper plant, cultivar BRS Tui. Brasília, Embrapa Hortaliças, 2015.

Foto: Francisco José B Reifschneider

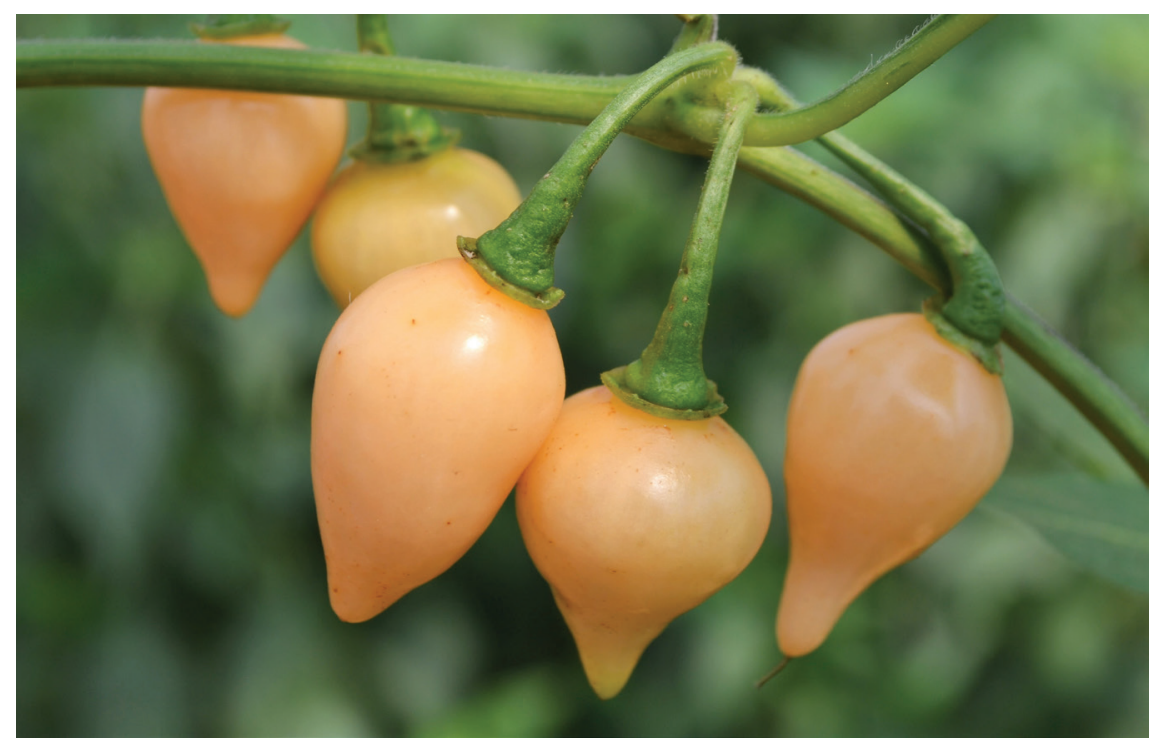

Figure 2. Biquinho pepper fruits, cultivar BRS Tui are light green when immature and light orange when ripe. Brasília, Embrapa Hortaliças, 2015. Foto: Francisco José B Reifschneider

height and $1.0 \mathrm{~m}$ width (Figure 1). The hanging fruits are pointed, triangular shaped, with smooth surface, light green color when immature and orangefleshed color when ripe (Figure 2), 1.8 $\mathrm{cm}$ long, $3.2 \mathrm{~cm}$ wide and $2.0 \mathrm{~mm}$ wall thickness. 'BRS Tui' fruits are extremely aromatic, tasty, and crunchy. In Central Brazil during the dry season, harvest begins around 90 days after seedlings are transplanted to the field.

'BRS Tui' presents field resistance to the tospoviruses Tomato Spotted Wilt Virus (TSWV) and Tomato Chlorotic
Spot Virus (TCSV), and to the potyviruses causing Pepper Yellow Mosaic Virus (PepYMV), and Potato Virus Y (PVY); resistance to Meloidogyne incognita; and intermediate resistance to Oidiopsis sicula and Xanthomonas euvesicatoria and $X$. gardneri.

'BRS Tui' demands high temperature for growing and is sensitive to low temperatures and intolerant to frost. In temperate regions, 'BRS Tui' should be grown in the warmer months. The new cultivar is recommended for open field, as well as protected (greenhouse/ screenhouse) cultivation. 'BRS Tui' yielded around $30 \mathrm{t} \mathrm{ha}^{-1}$ (23,000 plants $\mathrm{ha}^{-1}$ ) in field trials in Brasília-DF and three different sites in Goiás. The sweet and orange-fleshed fruits have negligible pungency of circa $170 \mathrm{SHU}$ (Scoville Heat Unit) and high content of vitamin C (205 mg $\left.100 \mathrm{~g}_{\text {of fruit }}{ }^{-1}\right)$.

'BRS Tui' was developed to meet both the fresh fruit market and the processing industries, particularly for production of pepper preserves, in addition to the potential use in many gourmet products such as sauces, jellies, flavored oils and vinegars, or even the ornamental pepper niche. The orange-fleshed fruit differentiates 'BRS Tui' from the other Biquinho pepper cultivars, with great potential to occupy new market niches.

\section{SEED MAINTENANCE AND DISTRIBUTION}

Embrapa Hortaliças will provide seeds of 'BRS Tui' under contract to interested seed-producing companies.

\section{ACKNOWLEDGEMENTS}

The authors thank CNPq (the Brazilian National Research and Development Council) and Sakura Nakaya Alimentos Ltda. for their support.

\section{REFERENCES}

CARVALHO, SIC; BIANCHETTI, LB; RIBEIRO, CSC; LOPES, CA. 2006. Pimentas do gênero Capsicum no Brasil. Brasília: Embrapa Hortaliças. 27p.

CARVALHO, SIC; BIANCHETTI, LB. 2008. Botânica e recursos genéticos. In: RIBEIRO, CSC; LOPES, CA; CARVALHO, SIC; HENZ, GP; REIFSCHNEIDER, FJB (org). Pimentas Capsicum. Brasília: Embrapa Hortaliças, p.39-53.

HEINRICH, AG; FERRAZ, RM; RAGASSI, CF; REIFSCHNEIDER, FJB. 2015. Caracterização e avaliação de progênies autofecundadas de pimenta biquinho salmão. Horticultura Brasileira 33: 465-470.

REIFSCHNEIDER, FJB; RIBEIRO, CSC; CARVALHO, SIC. 2013. Development of new Capsicum cultivars at Embrapa (Brazil). In: EUCARPIA MEETING ON GENETICS AND BREEDING OF CAPSICUM AND EGGPLANT, 15. Breakthroughs in the 


\section{CSC Ribeiro et al.}

Genetics and Breeding of Capsicum and Eggplant. Turim: Eucarpia, p.71-77.

REIFSCHNEIDER, FJB; LOPES, CA; RIBEIRO, CSC. 2016. Continuity, focus and impact: a commented historical perspective on Embrapa Vegetables' extended Capsicum breeding program. Horticultura Brasileira, 34: 155-160. RIBEIRO, CSC; REIFSCHNEIDER, FJB. 2008.

Genética e melhoramento. In: RIBEIRO, CSC; LOPES, CA; CARVALHO, SIC; HENZ, GP; REIFSCHNEIDER, FJB (org). Pimentas Capsicum. Brasilia: Embrapa Hortaliças, p.55-69.

RIBEIRO, CSC; SOUZA, KRR; CARVALHO, SIC; REIFSCHNEIDER, FJB. 2015. BRS Juruti: the first Brazilian habanero-type hot pepper cultivar. Horticultura Brasileira 33: 527-529. 